\title{
Genetic parameters to production characters of palm heart in half-sibs progenies of palm peach
}

\author{
Celso Luis Bergo ${ }^{1^{*}}$ (D) Daniela Popim Miqueloni ${ }^{2}$ (D) Cássia Ângela Pedrozo ${ }^{3}$ (D) \\ Marcos Deon Vilela de Resende ${ }^{4}$ (ID)
}

\author{
${ }^{1}$ Empresa Brasileira de Pesquisa Agropecuária (Embrapa) Acre, 69900-970, Rio Branco, AC, Brasil. E-mail: celso.bergo@embrapa.br. \\ ${ }^{*}$ Corresponding author. \\ ${ }^{2}$ Programa de Pós-graduação em Agronomia (Produção Vegetal), Universidade Federal do Acre (UFAC), Rio Branco, AC, Brasil. \\ ${ }^{3}$ Embrapa Roraima, Boa Vista, RR, Brasil. \\ ${ }^{4}$ Embrapa Florestas, Colombo, PR, Brasil.
}

\begin{abstract}
The peach palm (Bactris gasipaes) is a palm tree that produces palm heart originated of Amazonia with economic, social and environmental sustainability. To obtain improved cultivars it is necessary the evaluation and selection of genotypes with characteristics that support producers, manufacturing and consumers. In this context, the objective of this study was to estimate genetic parameters for palm heart production traits of peach palm considering half sibs progenies. Twenty progenies of Putumayo macrocarpa race were evaluated in seven cultivation cycles. The experiment was designed in complete randomized blocks, with 40 repetitions and one plant per plot. The genetic parameters were estimated by REML/BLUP methodology. Low genetic variability was observed in the population, possibly due to the narrow genetic base from original population. However, considering the significant genetic effect and the progeny mean heritability, the selection performed between progenies is more efficient than individual selection. The high number of measurements required for most of the evaluated characters becomes impractical in peach palm breeding programs. The number of palm heart per plant can be used to perform indirect selection for total production of palm heart.
\end{abstract}

Key words: Bactris gasipaes, yield, palm heart types.

Parâmetros genéticos para caracteres de produção de palmito em progênies de meio-irmãos de pupunheira

RESUMO: A pupunheira (Bactris gasipaes) é uma palmeira produtora de palmito oriunda da Amazônia, que apresenta sustentabilidade econômica, social e ambiental. Para a obtenção de cultivares melhoradas é necessário a avaliação e seleção de genótipos com características que atendam produtores, processadores e consumidores. Assim, o objetivo deste trabalho foi estimar parâmetros genéticos para os caracteres de produção de palmito de pupunha considerando progênies de meio-irmãos. Foram avaliadas 20 progênies da raça macrocarpa Putumayo em sete ciclos de cultivo. O experimento foi delineado em blocos completos ao acaso, com 40 repetições e uma planta por parcela. Os parâmetros genéticos foram estimados segundo metodologia REML/BLUP. Baixa variabilidade foi observada na população de estudo, possivelmente devido à estreita base genética da população original. Contudo, considerando o efeito genético significativo e as herdabilidades médias de progênie, a seleção praticada entre progênies é mais eficiente que a seleção individual. O grande número de medições necessárias para a maioria dos caracteres avaliados torna-se impraticável em programas de melhoramento de pupunheira. O número de palmitos por planta pode ser utilizado na seleção indireta para produção total de palmito.

Palavras-chave: Bactris gasipaes, rendimento, tipos de palmito.

\section{INTRODUCTION}

Recognition of a global market for palm heart and the availability of techniques for planting, handling and processing of peach palm (Bactris gasipaes Kunth) for palm heart, has generated a great increase in its cultivation and studies since 1990 (CLEMENT \& BOVI, 2000). Collection of palm heart through extractivism has reduced the natural reserves of 'açaí' and 'juçara' palms, being the peach palm an excellent option to obtain planted palm heart, besides decreasing the pressure of the extractive exploitation on these two palms, it has a high degree of tillering and does not show postharvest oxidation (RODRIGUES et al. 2017).

In general, the species has great genetic variability yet poorly characterized (MARTEL et al., 2003). According to MORA URPI \& CLEMENT (1988) and SOUSA et al. (2001), the peach palm was subdivided into primitive races formed by individuals that possess a set of morphological and functional characteristics transmitted by inheritance, and which were created by the first peoples of 
Amazon in thousands of years of domestication. Also according to these authors, in Brazil, along the Solimões and Amazon Rivers, three primitive breeds were proposed, using as main criterion of segregation fruts size. One of these is the Putumayo (macrocarpa) race, located along the upper Solimões River and adjacent areas in Colombia and Peru, which has large, starchy fruits.

Although the Putumayo race has originally been domesticated for production of fruits for human consumption, CLEMENT \& BOVI (1999) affirmed that its seeds, originated from progenies selected for palm heart production, have been used in the formation of commercial peach palm plantations in different regions of Brazil. In this context, according to the same authors, knowing the methods of cultivation and the ideal genetic material for each environment is essential for the proper use of the species, both for agronomic traits and for determination of the selection criteria.

Thus, the study of genetic parameters is fundamental in the design of the most efficient strategies for gains in production and yield. Studies have estimated genetic parameters of several species of palma of commercial interest (FARIAS NETO et al., 2004; OLIVEIRA \& MOURA, 2010; MANFIO et al., 2011), including peach palm (FARIAS NETO \& RESENDE, 2001; FARIAS NETO et al., 2013; KHALIL FILHO \& RESENDE, 2011, PADILHA et al., 2003). In the state of Acre, experiments with peach palm progenies are in progress (BERGO et al., 2013, NEGREIROS et al., 2013), which has provided the basis for selection of superior plants with consequent improvement of species. The objective of this study was to estimate genetic parameters for characters of palm heart production in half-sibs progenies of peach palm in the Brazilian Western Amazon.

\section{MATERIALS AND METHODS}

The half-sibs progenies test was installed in the experimental field of Embrapa Acre, Rio Branco, AC (10'1'30' S, 6742'18' W, about $160 \mathrm{~m}$ above sea level). The climate is Awi, hot and humid, according to Köppen classification, with annual average rainfall of $1,940 \mathrm{~mm}$, maximum and minimum temperatures of $31{ }^{\circ} \mathrm{C}$ and $21^{\circ} \mathrm{C}$ respectively, and relative humidity around $80 \%$ (INMET, 2017).

The soil of the experimental area is classified as Red Dystrophic aluminum Ultisol (SANTOS et al., 2013), with the following chemical and physical attributes of the layer from 0 to $0.2 \mathrm{~m}$ : $\mathrm{pH}$ in water: 4.9; Organic C: $11.1 \mathrm{~g} \mathrm{~kg}^{-1}$; P: $2.56 \mathrm{mg}$ $\mathrm{kg}^{-1} ; \mathrm{K}: 0.24 \mathrm{cmol}_{\mathrm{c}} \mathrm{kg}^{-1} ; \mathrm{Ca}: 2.34 \mathrm{cmol}_{\mathrm{c}} \mathrm{kg}^{-1} ; \mathrm{Mg}: 1.68$ cmol $\mathrm{kg}^{-1}$; Al: $1.15 \mathrm{cmol}_{\mathrm{c}} \mathrm{kg}^{-1}$; CEC: $5.40 \mathrm{cmol}_{\mathrm{c}} \mathrm{kg}^{-1}$; V: $30 \%$; m: $26 \%$; sand: $230 \mathrm{~g} \mathrm{~kg}^{-1}$; silt: $420 \mathrm{~g} \mathrm{~kg}^{-1}$; clay: $350 \mathrm{~g} \mathrm{~kg}^{-1}$.

Seeds for the test containing 20 halfsibs progenies of peach palm (only from known matrices) were collected at a commercial planting of the Reca project (Reflorestamento Econômico Consorciado Adensado/ Economic Reforestation Dense Consortium), located in Vila Nova California, RO. Seeds that gave rise to the commercial planting of Reca came from Peru, Yurimaguas. In commercial planting, we selected matrices with no spikes in the stipe and internodes above $20 \mathrm{~cm}$ to $1.2 \mathrm{~m}$ height from ground level.

The experimental design was randomized complete block with 20 treatments (progenies), 40 replicates, and the experimental plot consisted of a single plant. The experiment was conducted at spacing of $2.0 \mathrm{~m} \times 1.0 \mathrm{~m}$, without irrigation. Soil liming was not performed. In the planting the pits were fertilized with $2 \mathrm{~kg}$ of corral manure and $45 \mathrm{~g}$ of triple superphosphate. At 60 and 105 days post-planting were applied $25 \mathrm{~g}$ of ammonium sulfate and $15 \mathrm{~g}$ of potassium chloride. From the second year, plants were fertilized at the beginning (September), middle (January) and end of the rains (May), with $60 \mathrm{~g}$ of ammonium sulphate and $10 \mathrm{~g}$ of potassium chloride. In the first year of planting weed control was done by manual crown and mechanized weeding between the lines. After the first year, only mechanized weeding were done between the rows.

During seven cycles of palm heart production (from 2008 to 2014) the following characters were evaluated: palm heart total mass (PT), mass of palm heart base (PB), mass of the firstrate palm heart/stalks (FP), mass of the second-rate palm heart (SP), all in g; diameter of the first-rate palm heart (D) in $\mathrm{mm}$; number of stalks per palm heart (NS) and number of palm hearts per plant (NP), which represents the number of palm hearts extracted from a tussock. Mass of the second-rate palm heart represents the fractions of $9 \mathrm{~cm}$ stalks added to the mass of the basal and apical residue.

The data were analyzed by the methodology of mixed models REML/BLUP (Restricted Maximum Likelihood/Best Linear Unbiased Prediction), using deviance analysis to test effects of the model based on the Likelihood Ratio Test (LRT) (RESENDE, 2016). The model used was: $\mathrm{y}=\mathrm{Xm}+\mathrm{Za}+\mathrm{Tp}$ $+\mathrm{e}$, where $\mathrm{y}$ is the data vector, $\mathrm{m}$ the vector of measurement-repetition combination effects added to the general mean (considered fixed), a the vector 
of individual additive genetic effects (random), $\mathrm{p}$ the vector of individual permanent (random) effects through measurements, and e the residue vector. Capital letters represent the incidence matrices for these effects (RESENDE, 2002).

All parameters were determined according to RESENDE (2002). Individual narrow-sense heritability $\left(\mathrm{h}_{\mathrm{a}}^{2}\right)$ was obtained by: $\mathrm{h}_{\mathrm{a}}^{2}=\frac{\sigma_{\mathrm{a}}^{2}}{\sigma_{\mathrm{a}}^{2}+\sigma_{\mathrm{p}}^{2}+\sigma_{\mathrm{c}}^{2}}$, where $\sigma^{2}$ is the individual additive genetic variance; $\sigma_{p}^{2}$ the variance of permanent effects and $\sigma^{2}$ the residual variance. Individual repeatability (r) and the coefficient of determination of permanent effects $\left(\mathrm{c}^{2} \mathrm{p}\right) \underset{\sigma_{\mathrm{p}}^{2}}{\text { were respectively obtained by: } \mathrm{r}=\frac{\sigma_{\mathrm{a}}^{2}+\sigma_{\mathrm{p}}^{2}}{\sigma_{\mathrm{a}}^{2}+\sigma_{\mathrm{p}}^{2}+\sigma_{\mathrm{e}}^{2}}}$ and $\mathrm{c}_{\mathrm{p}}^{2}=\frac{\sigma_{\mathrm{p}}^{2}}{\sigma_{\mathrm{a}}^{2}+\sigma_{\mathrm{p}}^{2}+\sigma_{\mathrm{c}}^{2}}$

Coefficient of relative variation was given by: $\mathrm{CV}_{\mathrm{g}} / \mathrm{CV}_{\mathrm{e}}$, where the coefficients of genetic and residual variation are respectively: $\mathrm{CV}_{\mathrm{g}}=\frac{\sqrt{\sigma_{\mathrm{a}}^{2}}}{\text { mean }} 100$ and $\mathrm{CV}_{\mathrm{e}}=\frac{\sqrt{\sigma_{\mathrm{e}}^{2}}}{\text { mean }} 100$.

The heritability at the level of progeny means $\left(h^{2}{ }_{m p}\right)$ was given by $h_{m p}^{2}=\frac{[1+(b-1) 0.25] h_{m c}^{2}}{1+(b-1) 0.25 h^{2}}$ and the selective accuracy (Ac) was obtained by: $A c=\sqrt{h_{m p}^{2}}$, where $b$ is the number of blocks.

The heritability at the level of harvest means $\left(\mathrm{h}^{2}{ }_{\mathrm{mc}}\right)$ or cycles in an individual, based on the number of evaluations was given by: $h_{m}^{2}=\frac{m_{a}^{2}}{1+(m-1) r}$ and the Ac was obtained by: $A c=\sqrt{\frac{m_{a}^{2}}{1+(m-1) r}}$, where $\mathrm{m}$ is the number of measurements.

The number of measurements required (m) of each character to predict the actual value of genotypes, based on the predetermined coefficients of determination of $70 \%, 80 \%$ and $90 \%$, was calculated by: $m=\frac{R^{2}(1-r)}{\left(1-R^{2}\right) r}$, where $R^{2}$ is the coefficient of determination. Genetic and phenotypic correlations were obtained from the phenotypic and genotypic values, and tested at 5\% and probability using Student's t-test. All analyzes were performed by Selegen-REML/BLUP software (RESENDE, 2016).

\section{RESULTS AND DISCUSSION}

The estimates of variance components and genetic parameters of palm heart production characters of half-sibs progenies of peach palm can be seen in Table 1. The average of palm heart total mass per hectare (PT) obtained is considered high $(3,412 \mathrm{~kg}$ $\mathrm{ha}^{-1}$ year $\left.{ }^{-1}\right)$, being higher than the averages observed in the coast of São Paulo, by BOVI et al. (2004), which obtained less than 2,000 kg ha ${ }^{-1}$ (expected average productivity) with limestone application in the production area. The average production of firstrate palm heart (FP), that is, of stalks, was $964 \mathrm{~kg} \mathrm{ha}^{-1}$ year $^{-1}$, and the mass of palm heart base (PB) was of $2,084 \mathrm{~kg} \mathrm{ha}^{-1}$ year $^{-1}$, the FP being within the range of 860 to $1650 \mathrm{~kg} \mathrm{ha}^{-1}$ year $^{-1}$, and the $\mathrm{PB}$ greater than the range of 870 to $1390 \mathrm{~kg} \mathrm{ha}^{-1}$ year ${ }^{-1}$ observed by BOVI et al. (2007), with increasing doses of sewage sludge as fertilizer. The observed means of the FP were also higher than those obtained by YUYAMA et al. (2005) for peach palm, which obtained 840 $\mathrm{kg} \mathrm{ha}^{-1}$ in the first harvest at 18 months, but lower than that observed by FARIAS NETO \& RESENDE (2001), with about $1,135 \mathrm{~kg} \mathrm{ha}^{-1}$, both in the Amazon region. These two characters are of great interest in the selection process, since the total mass of the palm heart is linked directly with the commercialization in the form of first-rate palm heart or stalks, which, according to CLEMENT \& BOVI (2000), determines the "quality of export" and also the chopped extracted from the basal part of the palm heart (KALIL FILHO et al., 2010). In addition to composing the characters of production, these two forms of sale are those that most affect the commercial viability of the crop (CORDEIRO \& SILVA, 2010).

The genetic effects were significant $(\mathrm{P} \leq 0.05)$ for the characters palm heart total mass (PT), mass of palm heart base (PB), first-rate palm heart/ stalks (FP), diameter of the first-rate palm heart (D) and number of palm hearts per plant (NP) (Table 1). There were not significant differences among progenies for the remaining characters. Estimates of individual additive genetic variance $\left(\sigma^{2}\right)$ were lower than the environmental variances, especially the residual variance $\left(\sigma_{\mathrm{e}}^{2}\right)$. These results indicated that, in general, the characters evaluated were highly influenced by the environment conditions, mainly by those with a temporary effect, such as climatic conditions and management. Moreover, they showed low genetic variability of the study population, probably due to the various selection cycles by which the original population has passed and possibly to common origin (CLEMENT \& BOVI, 1999).

With the exception of the number of palm hearts per plant (NP), the permanent environment effects were significant for all other characters, which suggested the existence of specific environmental conditions that favored the development of plants in some plots. According to VIANA \& RESENDE (2014), the permanent effects, or of plot, begin to act after planting and remain during the evaluations. This occurs, for example, due to soil structure and fertility, and microclimate in the plot. Thus, the lack of significance for the NP indicated that the permanent environment had less punctual influence in this character.

The coefficients of determination of the permanent effects $\left(\mathrm{c}_{\mathrm{p}}^{2}\right)$, related to the individual permanent environment variance; although low, 
Table 1 - Estimates of variance components and genetic parameters of characters such as, palm heart total mass (PT), mass of palm heart base (PB), mass of the first-rate palm heart/stalks (FP), mass of the second-rate palm heart (SP), diameter of the first-rate palm heart (D), number of palm hearts per plant (NP), number of stalks per palm heart (NS) of an experiment with 20 half-sibs progenies of peach palm.

\begin{tabular}{|c|c|c|c|c|c|c|c|}
\hline Parameter & PT(kg ha $\left.{ }^{-1}\right)$ & $\mathrm{PB}\left(\mathrm{kg} \mathrm{ha} \mathrm{h}^{-1}\right)$ & $\mathrm{FP}\left(\mathrm{kg} \mathrm{ha}^{-1}\right)$ & $\mathrm{SP}\left(\mathrm{kg} \mathrm{ha} \mathrm{p}^{-1}\right)$ & $\mathrm{D}(\mathrm{mm})$ & NP & NS \\
\hline$\sigma_{a}^{2}$ & $147,298^{*}$ & $78,501^{* *}$ & $12,744^{*}$ & $1.893^{\mathrm{ns}}$ & $1.2234^{* *}$ & $0.0164^{*}$ & $0.0283^{\mathrm{ns}}$ \\
\hline$\sigma_{p}^{2}$ & $296,867^{* *}$ & $122,463^{* *}$ & $21,517^{* *}$ & $4.431^{* *}$ & $1.9072^{* *}$ & $0.0142^{\mathrm{ns}}$ & $0.2137^{*}$ \\
\hline$\sigma_{\mathrm{e}}^{2}$ & $3,564,405$ & $1,537,856$ & 404,379 & 66.626 & 16.4884 & 0.6036 & 5.3778 \\
\hline$\sigma_{\mathrm{f}}^{2}$ & $4,008,570$ & $1,738,819$ & 438,640 & 72.951 & 19.6191 & 0.6341 & 5.6197 \\
\hline $\mathrm{h}_{\mathrm{a}}^{2}$ & $0.04 \pm 0.02$ & $0.05 \pm 0.02$ & $0.03 \pm 0.02$ & $0.03 \pm 0.02$ & $0.06 \pm 0.03$ & $0.03 \pm 0.02$ & $0.01 \pm 0.01$ \\
\hline $\mathrm{h}_{\mathrm{mp}}^{2}$ & 0.66 & 0.71 & 0.63 & 0.59 & 0.76 & 0.64 & 0.24 \\
\hline $\mathrm{r}$ & $0.11 \pm 0.02$ & $0.12 \pm 0.02$ & $0.08 \pm 0.01$ & $0.09 \pm 0.02$ & $0.16 \pm 0.02$ & $0.05 \pm 0.01$ & $0.04 \pm 0.01$ \\
\hline$c_{p}^{2}$ & 0.07 & 0.07 & 0.05 & 0.06 & 0.10 & 0.02 & 0.04 \\
\hline Ac & 0.81 & 0.84 & 0.80 & 0.77 & 0.87 & 0.80 & 0.49 \\
\hline $\mathrm{CV}_{\mathrm{g}}$ & 11.25 & 13.44 & 11.71 & 10.64 & 4.28 & 8.89 & 4.38 \\
\hline $\mathrm{CV}_{\mathrm{e}}$ & 55.33 & 59.49 & 65.95 & 63.12 & 15.72 & 53.97 & 60.43 \\
\hline $\mathrm{CVr}$ & 0.20 & 0.23 & 0.18 & 0.17 & 0.27 & 0.16 & 0.07 \\
\hline Mean & $3,412.08$ & $2,084.58$ & 964.23 & 408.96 & 25.83 & 1.44 & 3.84 \\
\hline \multicolumn{8}{|c|}{ 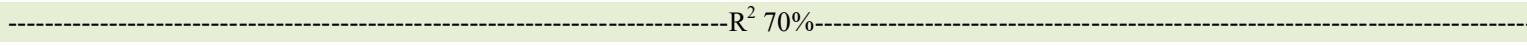 } \\
\hline M & 19 & 18 & 27 & 25 & 13 & 46 & 51 \\
\hline $\mathrm{h}_{\mathrm{mc}}^{2}$ & 0.23 & 0.27 & 0.26 & 0.21 & 0.28 & 0.38 & 0.08 \\
\hline Ac & 0.48 & 0.52 & 0.51 & 0.46 & 0.53 & 0.61 & 0.29 \\
\hline Ef & 2.52 & 2.46 & 2.98 & 2.85 & 2.11 & 3.81 & 4.02 \\
\hline \multicolumn{8}{|c|}{ 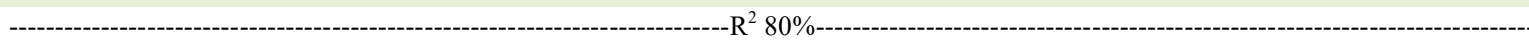 } \\
\hline $\mathrm{m}$ & 32 & 30 & 46 & 41 & 21 & 77 & 87 \\
\hline $\mathrm{h}_{\mathrm{mc}}^{2}$ & 0.27 & 0.31 & 0.30 & 0.24 & 0.31 & 0.43 & 0.09 \\
\hline Ac & 0.51 & 0.56 & 0.54 & 0.49 & 0.56 & 0.65 & 0.31 \\
\hline Ef & 2.69 & 2.63 & 3.19 & 3.03 & 2.24 & 4.06 & 4.30 \\
\hline \multicolumn{8}{|c|}{ - } \\
\hline M & 69 & 66 & 101 & 90 & 45 & 169 & 190 \\
\hline $\mathrm{h}_{\mathrm{mc}}^{2}$ & 0.30 & 0.35 & 0.33 & 0.27 & 0.35 & 0.48 & 0.10 \\
\hline Ac & 0.55 & 0.59 & 0.58 & 0.53 & 0.59 & 0.69 & 0.32 \\
\hline $\mathrm{Ef}$ & 2.84 & 2.78 & 3.39 & 3.21 & 2.37 & 4.31 & 4.56 \\
\hline
\end{tabular}

** and ${ }^{*}$ significant at level $1 \%$ and $5 \%$ of probability, respectively, by the Chi-square test; ${ }^{\mathrm{ns}}$ not significant; $\sigma_{\mathrm{a}}^{2}$ : individual additive genetic variance; $\sigma_{\mathrm{p}}^{2}$ : variance of permanent effects; $\sigma_{\mathrm{e}}^{2}$ : residual variance; $\sigma_{\mathrm{f}}^{2}$ : individual phenotypic variance; $\mathrm{h}_{\mathrm{a}}^{2}$ : individual narrow-sense heritability; $\mathrm{h}_{\mathrm{mp}}^{2}$ : heritability at the level of progeny means; $\mathrm{r}$ : individual repeatability; $\mathrm{c}_{\mathrm{p}}^{2}$ : coefficient of determination of permanent effects; Ac: selective accuracy; $\mathrm{CV}_{\mathrm{g}}$ : coefficient of genetic variation; $\mathrm{CV}_{\mathrm{e}}$ : coefficient of residual variation; $\mathrm{R}^{2}$ : coefficient of determination; Ef: selective efficiency compared to a single measurement; $h^{2}{ }_{\text {mc }}$ : heritability at the level of harvest means.

presented a greater magnitude than the individual genetic effect $\left(\mathrm{h}_{\mathrm{a}}^{2}\right)$, indicating that the environmental variation; although significant, was low from year to year for most of the characters.

Estimates of individual narrow-sense heritability $\left(\mathrm{h}^{2}{ }_{\mathrm{a}}\right)$ are considered low, according to a criterion established by RESENDE (2002), which is common for quantitative characters in perennial plants. These results are a consequence of the low estimates of $\sigma^{2}$ and indicate a reduced possibility of gains with the individual selection, within progeny, for the palm heart production in the population.
Heritability at the level of progeny means $\left(h^{2}{ }_{m p}\right)$ varied from medium to high, indicating; therefore, a greater selection potential among progenies (VIANA \& RESENDE, 2014)

Low estimates of $\mathrm{h}^{2}$ for the palm heart mass character in peach palm trees evaluated in Paraná were reported by KALIL FILHO \& RESENDE (2011). Except for plant height and palm heart size, FARIAS NETO \& RESENDE (2001) also obtained low estimates of heritability for characters of palm heart production in Amapá. According to the latter authors, a possible cause for low heritability estimates 
may be related to the narrow genetic base of the population evaluated, also coming from Yurimaguas and from previous selection cycles (CLEMENT \& BOVI, 1999). In fact, this narrow genetic base may explain the low estimates of $\sigma^{2}$ and $h^{2}$ obtained, since the progenies of this experiment come from a single planting area of the RECA project, which also comes from Yurimaguas seeds in Peru.

There is no information of the genetic variability of the mentioned base population and, according to ARAÚJO et al. (2010) and SOUSA et al. (2001), the peach palm tree tends to show a spatial genetic structure according to the Amazon regions of origin. KALIL FILHO (2011) commented that the genetic factors have a direct influence on the quality of palm heart, and the geographic distance is an indicative of the genetic distance of the populations due to the selection pressures applied in each peach palm population. Thus, the importance of effective population size in genetic improvement is critical, since it may lead to the occurrence of genetic drift and inbreeding increased, and should be kept at a safe level at each sampling to avoid favorable alleles loss to be fixed (ARANTES et al., 2010, RESENDE, 2002). So, the 20 progenies evaluated in this study may not have been enough to capture the genetic variability of the original population, suggesting an increase in the collection area and in the number of plants to be studied.

Selective accuracy (Ac) refers to the correlation between the predicted genetic values and the true genetic values of individuals (RESENDE, 2002). According to VIANA \& RESENDE (2014), accuracies greater than $70 \%$ are desirable in the initial and intermediate stages of breeding. In this study, except for the NS character, accuracy was obtained with values above $70 \%$ for all other characters.

Coefficients of genetic variation $\left(\mathrm{CV}_{\mathrm{g}}\right)$ were lower than the coefficients of residual variation $\left(\mathrm{CV}_{\mathrm{e}}\right)$ for all the characters. Thus, the coefficient of relative variation for the evaluated characters was lower than the unit, indicating little possibility of obtaining genetic gains with the selection of genotypes (VENCOVSKY, 1987).

In perennial species, it is expected that the initial superiority after the selection of a given genotype persists through the whole cycle, that is, high repeatability of the interest characters is expected (RESENDE, 2002). Estimates of individual repeatability (r) were low, ranging from 0.04 to 0.16 for NS and diameter of the first-rate palm heart (D) characters, respectively (Table 1). Based on these values of $r$ it was possible to estimate the need of more than 20 measurements for all the characters to obtain a coefficient of determination $\left(\mathrm{R}^{2}\right)$ of $80 \%$. Low repeatability estimates reflect the low additive variance compared to the residual variance, confirming the difficulties in selecting superior genotypes based on few measurements with only individual information. The large number of measurements required for most of the characters obtained in the present study becomes impractical in peach palm breeding programs, even with the increase of efficiency and selective accuracy, observed with the increase in the number of measurements (Table 1).

An alternative for the improvement of this peach palm tree population is the individual BLUP with repeated measures, which combines the information of the individual in the seven cutting cycles and the average of its family.

In Belém, in the state of Pará, PADILHA et al. (2003) also observed low repeatability for characters of palm heart production in the initial phase of breeding, which suggested irregularity in the superiority of the plants from one year to the other. In contrast, BERGO et al. (2013) and FARIAS NETO et al. (2002) obtained higher values of repeatability, with three to seven cycles of measurements indicated as sufficient to predict the real value of the palm heart production characters, with coefficient of determination higher than $85 \%$.

The majority of the phenotypic correlations were of low magnitude (Table 2), indicating the difficulty of the indirect selection practice using this type of data. BERGO et al. (2013) and PADILHA et al. (2003) also reported difficulties in the selection of desirable individuals considering only the phenotypic characters for the species, which highlighted the importance of the use of genetic information in populations of lower variability. PB presented high phenotypic correlations with NS and SP (0.962 and 0.801 , respectively), while FP presented a high correlation with SP (0.865). Moderate phenotypic correlations were obtained by the combinations FP $x$ PB (0.786), FP x NS (0.698) and NS x SP (0.652), all significant. Regarding genotype correlations, in general, higher values were reported between palm heart mass characters and moderate correlations between NP and PT, PB and NS characters (above 0.739 , all significant). Results of the genotypic correlations indicated that both NS with low accuracy and NP could be used for indirect selection for PT and PB. The NP, to be easily measured, becomes an interesting character for indirect selection aiming the productive increase of palm heart. 
Table 2 - Genetic (above diagonal) and phenotypic (below diagonal) correlations of palm heart production characters in progenies of peach palm trees.

\begin{tabular}{lccccccc}
\hline Character & PT & PB & NS & FP & SP & D & NP \\
\hline PT & - & 0.973 & 0.893 & 0.821 & 0.616 & 0.314 & 0.739 \\
PB & $0.108^{\text {ns }}$ & - & 0.849 & 0.691 & 0.562 & 0.185 & 0.757 \\
NS & 0.156 & 0.962 & - & 0.815 & 0.440 & 0.161 & 0.764 \\
FP & $0.124^{\text {ns }}$ & 0.786 & 0.698 & - & 0.362 & 0.602 & $0.071^{\text {ns }}$ \\
SP & 0.180 & 0.801 & 0.652 & 0.865 & 0.581 & - \\
D & -0.399 & 0.522 & 0.424 & 0.221 & 0.246 & -0.167 \\
NP & $-0.062^{\text {ns }}$ & 0.209 & $0.072^{\text {ns }}$ & $0.031^{\text {ns }}$ & 0.360 & 0.280 \\
\hline
\end{tabular}

ns: not significant by Student's t-test at 5\% probability; PT: palm heart total mass; PB: mass of palm heart base; NS: number of stalks per palm heart; FP: mass of the first-rate palm heart/stalks; SP: mass of the second-rate palm heart; D: diameter of the first-rate palm heart; NP: number of palm hearts per plant.

\section{CONCLUSIONS}

There is low genetic variability among halfsibs progenies of peach palm evaluated. Estimates of heritability at the level of progeny means ranged from median to high for most of the evaluated characters, showing a greater possibility of selection among progenies in the population than among individuals.

The large number of measurements required for most of the evaluated characters make their use in their totality impractical in breeding programs of the treated species, reason why it is suggested to use the number of palm heart per plant (NP) character in indirect selection for the production of total, base and first-rate palm heart, due to high genotypic correlations with these characters.

\section{ACKNOWLEDGEMENTS}

To Empresa Brasileira de Pesquisa Agropecuária (EMBRAPA), Universidade Federal do Acre (UFAC) and Coordenação de Aperfeiçoamento de Pessoal de Nível Superior (CAPES) for providing financial resources and scholarship to the second author.

\section{DECLARATION OF CONFLICT OF INTERESTS}

The authors declare no conflict of interest. The founding sponsors had no role in the design of the study; in the collection, analyses, or interpretation of data; in the writing of the manuscript, and in the decision to publish the results.

\section{AUTHORS' CONTRIBUTIONS}

CLB conceived, designed and performed the experiments, CAP and MDVR performed statistical analyses of experimental data. DPM prepared the draft of the manuscript. All authors critically revised the manuscript and approved of the final version.

\section{REFERENCES}

ARANTES, F.C. et al. Ganho genético com base no tamanho efetivo populacional de progênies de seringueira. Pesquisa Agropecuária Brasileira, Brasília, DF, v.45, n.12, p.14191424, dez. 2010. Available from: <http://www.scielo.br/scielo. php?script $=$ sci arttext \&pid=S0100-204X2010001200012\&lng $=$ en $\&$ nrm $=$ iso $\&$ tlng $=$ pt $>$. Accessed: Apr. 12, 2018. doi: 10.1590/ S0100-204X2010001200012.

ARAÚJO, M. de C. et al. Genetic variability in the peach palm genebank with RAPD markers. Crop Breeding and Applied Biotechnology, Viçosa, MG, v.10, n.3, p.211-217, set. 2010. Available from: $<$ http://www.scielo.br/scielo.php?script=sci_artte xt\&pid=S1984-70332010000300005>. Accessed: Apr. 12, 2018. doi: 10.1590/S1984-70332010000300005.

BERGO, C.L. et al. Estimativas de repetibilidade de caracteres de produção em pupunheiras para palmito da raça Putumayo. Revista Brasileira de Fruticultura, Jaboticabal, v.35, n.3, p.829836, set. 2013. Available from: <http://www.scielo.br/scielo. php?script $=$ sci_arttext \&pid=S0100-29452013000300020\&lng $=$ en $\&$ nrm $=$ iso $>$. Accessed: Apr. 12, 2018. doi: 10.1590/S010029452013000300020.

BOVI, M.L.A. et al. Lodo de esgoto e produção de palmito em pupunheira. Revista Brasileira de Ciência do Solo, Viçosa, MG, v.31, n.1, p.153-166, fev. 2007. Available from: <http:// www.scielo.br/scielo.php?script $=$ sci_arttext\&pid $=$ S0100$06832007000100016 \& \operatorname{lng}=$ en $\& n r m=$ iso \&tlng $=\mathrm{pt}>$. Accessed: Apr. 12, 2018. doi: 10.1590/S0100-06832007000100016.

BOVI, M.L.A. et al. Peach palm growth and heart-of-palm yield responses to liming. Revista Brasileira de Ciência do Solo, Viçosa, MG, v.28, n.6, p.1005-1012, dez. 2004. Available from: $\quad<\mathrm{http}$ ://www.scielo.br/scielo.php?script=sci arttext\&pid $=$ S0100-06832004000600009>. Accessed: Apr. 12, 2018. doi: 10.1590/S0100-06832004000600009.

Ciência Rural, v.49, n.7, 2019. 
CLEMENT, C.R; BOVI, M.L.A. Melhoramento genético de pupunheira: conhecimentos atuais e necessidades. In: SEMINÁRIO DO AGRONEGÓCIO PALMITO DE PUPUNHA NA AMAZÔNIA, 1., 1999, Porto Velho, Anais... Porto Velho: Embrapa-CPAF Rondônia, 1999. p.57-70.

CLEMENT, C.R.; BOVI, M.L.A. Padronização de medidas de crescimento e produção em experimentos com pupunheira para palmito. Acta Amazonica, Manaus, AM, v.30, n.3, p.349-362, 2000. Available from: <https://acta.inpa.gov.br/fasciculos/30-3/ PDF/v30n3a01.pdf>. Accessed: Apr. 12,. 2018.

CORDEIRO, S.A.; SILVA, M.L. da. Rentabilidade e risco de investimento na produção de palmito de pupunha (Bactris gasipaes Kunth.). Cerne, Lavras, MG, v.16, n.1, p.53-59, mar. 2010. Available from: $<$ http://www.scielo.br/scielo.php?script $=$ sci arttext\&pid=S0104-77602010000100006\&lng=en\&nrm $=$ is o\&tlng $=$ pt $>$. Accessed: Apr. 12, 2018. doi: 10.1590/S010477602010000100006 .

FARIAS NETO, J.T. et al. Estimativas de parâmetros genéticos e ganho de seleção para produção de frutos em progênies de polinização aberta de pupunheira no Estado do Pará, Brasil. Bragantia, Campinas, SP, v.72, n.2, p.122-126, jun. 2013. Available from: $<$ http://www. scielo.br/scielo.php?script $=$ sci arttext\&pid $=\mathrm{S} 0006-87052013000200002 \& \operatorname{lng}=\mathrm{en} \& \mathrm{nrm}=\mathrm{is}$ so \&tlng=pt $>$. Accessed: Apr. 12, 2018. doi: 10.1590/S000687052013000200002 .

FARIAS NETO, J.T. et al. Estimativas de correlação e repetibilidade para caracteres do fruto de bacurizeiro. Ciência e Agrotecnologia, Lavras, MG, v.28, n.2, p.300-305, 2004. Available from: <https:// www.embrapa.br/busca-de-publicacoes/-/publicacao/406924/ estimativas-de-correlacao-e-repetibilidade-para-caracteres-dofruto-de-bacurizeiro>. Accessed: Apr. 12, 2018.

FARIAS NETO, J.T. et al. Coeficientes de repetibilidade genética de caracteres em pupunheiras. Revista Brasileira de Fruticultura, Jaboticabal, SP, v.24, n.3, p.731-733, 2002. Available from: $<$ http://www.scielo.br/scielo.php?script=sci_arttext\&pid=S010029452002000300042\&lng=en\&nrm=iso\&tlng $=\mathrm{pt}>$. Accessed: Apr. 12, 2018. doi: 10.1590/S0100-29452002000300042.

FARIAS NETO, J.T.; RESENDE, M.D.V. de. Aplicação da metodologia de modelos mistos (REML/BLUP) na estimação de componentes de variância e predição de valores genéticos em pupunheira (Bactris gasipaes). Revista Brasileira de Fruticultura, Jaboticabal, SP, v.23, n.2, p.320-324, ago. 2001. Available from: $<$ http://www.scielo.br/scielo.php?script=sci_arttext\&pid $=\mathrm{S} 0100$ $29452001000200024 \& \operatorname{lng}=\mathrm{en} \& \mathrm{nrm}=\mathrm{iso} \& \ln \mathrm{l}=\mathrm{pt}>$. Accessed: Apr. 12, 2018. doi: 10.1590/S0100-29452001000200024.

INMET - Instituto Nacional de Meteorologia. BDMEP: Banco de Dados Meteorológicos para Ensino e Pesquisa. Disponível em: $<$ http://www.inmet.gov.br/portal/index.php?r=bdmep/bdmep $>$. Accessed: Jan. 23, 2017.

KALIL FILHO, A.N. Melhoramento para palmito - Embrapa. In: SIMPÓSIO BRASILEIRO DA PUPUNHEIRA, 1., 2011, Ilhéus. Anais... Ilhéus: CEPLAC, 2011. 1 CD-ROM.

KALIL FILHO, A.N.; RESENDE, M.D.V. de. Melhoramento da pupunha para palmito no Paraná. In: SIMPÓSIO BRASILEIRO DA PUPUNHEIRA, 1., 2011, Ilhéus. Anais... Ilhéus: CEPLAC, 2011. 1 CD-ROM.
KALIL FILHO, A.N. et al. Programa de melhoramento genético de pupunha na Embrapa, IAC e Inpa. Colombo: Embrapa Florestas, 2010. 34p. (Documentos, 205). Available from: <https:/www.embrapa.br/florestas/busca-de-publicacoes/-/ publicacao/882495/programa-de-melhoramento-genetico-depupunha-na-embrapa-iac-e-inpa>. Accessed: Apr. 12, 2018.

MANFIO, C.E. et al. Repetibilidade em características biométricas do fruto de macaúba. Ciência Rural, Santa Maria, RS, v.41, n.1, p.70-76, 2011. Available from: $<$ http://www.scielo.br/scielo. php?script $=$ sci_arttext\&pid $=$ S0103-84782011000100012>. Accessed:Apr. 12, 2018. doi: 10.1590/S0103-84782011000100012.

MARTEL, J.H.I. et al. Estatística multivariada na discriminação de raças amazônicas de pupunheiras (Bactris gasipaes Kunth.) em Manaus, AM. Revista Brasileira de Fruticultura, Jaboticabal, v.25, p.1-9, 2003. Available from: <http://www.scielo.br/scielo. php?script $=$ sci_arttext\&pid=S0100-29452003000100033\&lng= en\&nrm=iso\&tlng=pt>. Accessed: Apr. 12, 2018. doi: 10.1590/ S0100-29452003000100033.

MORA URPI, J.; CLEMENT, C.R. Races and population of peach palm found in the Amazon basin. In: CLEMENT, C.R.; CORANDIN, L. Peah palm germplasm bank. Manaus: INPA, 1988. p.78-94.

NEGREIROS, J.R. da S. et al. Divergência genética entre progênies de pupunheira quanto a caracteres de palmito. Pesquisa Agropecuária Brasileira, Brasília, DF, n.48, n.5, p.496-503, maio 2013. Available from: <http://www.scielo.br/scielo. php?script $=$ sci_arttext\&pid $=$ S0100-204X2013000500005\&lng $=$ en $\& n r m=$ iso $\&$ tlng $=$ pt $>$. Accessed: Apr. 12, 2018. doi: 10.1590/ S0100-204X2013000500005.

OLIVEIRA, M. do S.P. de; MOURA, E.F. Repetibilidade de número mínimo de medições para caracteres de cacho de bacabi (Oenocarpus mapora). Revista Brasileira de Fruticultura, Jaboticabal, SP, v.32, n.4, p.1173-1179, 2010. Available from: $<$ http://www.scielo.br/scielo.php?script=sci_arttext\&pid $=$ S0100-29452010000400027 $>$. Accessed: Apr. 12, 2018. doi: $10.1590 / \mathrm{S} 0100-29452010005000120$.

PADILHA, N.C.C. et al. Estimativa de repetibilidade em caracteres morfológicos e de produção de palmito em pupunheira (Bactris gasipaes Kunth). Revista Árvore, Viçosa, MG, v.27, n.4, p.435-442, 2003. Available from: <http://www.scielo.br/scielo. php?script $=$ sci_ arttext\&pid=S0100-67622003000400003\&lng $=$ en\&nrm=iso $\&$ tlng=pt $>$. Accessed: Apr. 12, 2018. doi: 10.1590/ S0100-67622003000400003.

RESENDE, M.D.V. de. Genética biométrica e estatística no melhoramento de plantas perenes. Brasília, DF: Embrapa Informação Tecnológica, 2002.975p.

RESENDE, M.D.V. de. Sofware Selegen-REML/BLUP: a useful tool for plant breeding, Crop Breeding and Applied Biotechnology, Viçosa, MG, v.16, n.4, p.330-339, out./dez. 2016. Available from: <http://www.scielo.br/scielo.php?script=sci_artt ext\&pid=S1984-70332016000400330 $>$. Accessed: Apr. 11, 2018. doi: 10.1590/1984-70332016v16n4a49.

RODRIGUES, H.S. et al. Genetic variability and progeny selection of peach palm via mixed models (REML / BLUP). Acta Scientiarum. Agronomy, Maringá, PR, v.39, n.2, p.165-173, Apr./June, 2017. 
Available from: http://www.scielo.br/scielo.php?script=sci_arttext \&pid=S1807-86212017000200165 Accessed: Apr. 12, 2018. doi: 10.4025/actasciagron.v39i2.32495.

SANTOS, H.G. dos. et al. Sistema brasileiro de classificação de solos. 3.ed. Brasília, DF: Embrapa, 2013. 353p.

SOUSA, N.R. et al. Discriminação de raças primitivas de pupunha (Bactris gasipaes) na Amazônia por meio de marcadores moleculares (RAPDS). Acta Amazonica, Manaus, v.31, n.4 p.539-545, 2001. Available from: <http://www.scielo.br/scielo.
php?script=sci_arttext\&pid=S0044-59672001000400539\&lng=en $\& n r m=i s o \& t \operatorname{lng}=p t>$. Accessed: Apr. 12, 2018. doi: 10.1590/180943922001314545 .

VENCOVSKY, R. Herança quantitativa. In: PATERNIANI, E.; VIEGAS, V.P. Melhoramento e produção de milho. 2. ed. Campinas: Fundação Cargill, 1987. p. 137-214.

VIANA, A.P.; RESENDE, M.D.V. de. Genética quantitativa no melhoramento de fruteiras. Rio de Janeiro: Interciência, FAPERJ, 2014. 296p. 